\title{
EDITORIAL
}

\section{The branding, marketing and embodied practice of contemporary yoga}

W hen Dr Ruth Illman, the editor of Approaching Religion, asked me to step in as guest editor of the current issue, she was quick to sell such a pro bono task by indicating that I could build the issue around any topic that I wanted. Being presently engaged in yoga research myself, I am sure she was not very surprised that I wished to make this a yoga issue.

Academic research into yoga is a burgeoning field; something that is indicated by a steadily growing number of excellent publications, both when it comes to mainly textual studies on the history of yoga in southern Asia (e.g. White 2012) and more ethnographically-oriented research on the 'transnational cultural project' (Strauss 2005: 9) of modern yoga practice (e.g. Alter 2004, Singleton \& Byrne 2008). As I see it, yoga research has three things going for it. Firstly, the texts illuminating the history of yoga, besides being intrinsically interesting in terms of content, with all their blood, sex and weird magic, offer plenty of challenges both in terms of textual history and their connection with south Asian society at large (see Samuel 2008 for a provocative and genuinely comprehensive historical study).

Secondly, yoga is an important and growing trend in popular culture in the West. In Finland, according to a recent survey (Kirkon tutkimuskeskus 2012: 2237) more people engage in yoga or other 'techniques of spiritual growth' on a weekly basis than read the Bible. While it is doubtful that all of the practitioners of what Elisabeth De Michelis (2004) has famously called 'modern postural yoga' view their practice in terms of religion, or even 'spirituality', they nevertheless present a wide and fruitful field for studying many of the aspects of our late modern or post-secular society.
Thirdly, many or perhaps most scholars of yoga are yoga practitioners of one sort or other themselves, something that no doubt motivates their own study of the yoga traditions (who studies something they are not personally interested in anyway?), but that can make them interesting research objects as well. Such dual roles also illustrate the way in which yoga transgresses, transforms and indeed blurs the boundaries between sports, practices of well-being and worldviews.

This issue opens with Andrea Jain's article on branding yoga. By looking at the evolution of Iyengar Yoga, Siddha Yoga, and Anusara Yoga, Dr Jain illustrates how the model of brand image management is useful for understanding the broader phenomenon of the contemporary global popularisation of postural yoga. This article is followed by my own on yoga in cyberspace, using the yoga studios of Turku, Finland as my material. With the help of Heidi Campbell's concept of networked religions, I examine the ways in which these yoga studios use or decline to use the possibilities of the internet and new media for defining and indeed marketing themselves.

From branding and marketing we then come to the bodily practice of modern postural yoga. In his article, using extensive fieldwork among practitioners of Astanga Vinyasa Yoga in Mysore, India, Lars Jørun Langøien argues that while the religio-spiritual interests of many aspiring yogis may not be strictly Hindu in origin, they are spiritual in the sense of pointing towards higher meanings and authorities. The embodied practice itself may thus become a catalyst of different kinds of changes in the lives of practitioners. Finally, Hanna-Leena Ylönen continues with this theme of change, but in another way, by examining the ways in which Catholic practitioners of yoga in Buenos Aires, Argentina see yoga as changing 
their conception of themselves and the world - while they remain committed Catholics. Ylönen also offers a very useful overview of the literature of bodily research in the social sciences. This issue closes with two reviews of relevant books recently published, by Sofia Sjö and Matti Rautaniemi.

Now, knowing that I am also a Sanskritist, it is possible that Dr Illman may have hoped for/ dreaded another type of special issue. Alas, as the poet has it,

\section{अनन्तं शास्त्रं बहुलच्च विद्या अल्पस्तु कालः}

The scripture is endless, the sciences are manifold, but time is short. Perhaps another time?

MÅNS BROO

Guest Editor

\section{References}

Alter, Joseph 2004. Yoga in Modern India: The Body between Science and Philosophy. Princeton: Princeton University Press.

De Michelis, Elisabeth 2004. A History of Modern Yoga: Patañjali and Western Esotericism. London and New York: Continuum.

Kirkon tutkimuskeskus 2012. Haastettu kirkko. Suomen evankelis-luterilainen kirkko vuosina 20o8-2011. Kirkon tutkimuskeskuksen julkaisuja 115. Tampere: Kirkon tutkimuskeskus.

Samuel, Geoffrey 2008. The Origins of Yoga and Tantra: Indic Religions to the Thirteenth Century. Cambridge: Cambridge University Press.

Singleton, Mark \& Jean Byrne (eds) 2008. Yoga in the Modern World: Contemporary Perspectives. London \& New York: Routledge Hindu Studies Series.

Strauss, Sarah 2005. Positioning Yoga: Balancing Acts across Cultures. Oxford: Berg.

White, David Gordon (ed.) 2012. Yoga in Practice. Princeton and Oxford: Princeton University Press. 